\title{
Agnieszka Teterycz-Puzio: Konrad I Mazowiecki. Kniaź wielki lacki (1187/89-31 sierpnia 1247). Kraków, Avalon, 2019, ss. 267
}

Konrad Mazowiecki to $\mathrm{z}$ całą pewnością wybitny władca swojej epoki. Bez wątpienia zasługuje na rzetelne opracowanie swoich rządów. W 2008 roku ukazała się biografia księcia autorstwa Henryka Samsonowicza. Panowanie Konrada zostało wówczas ukazane jako przede wszystkim element historii Polski i Europy, a co za tym idzie - nie wszystkie aspekty działalności władcy mogły zostać dogłębnie zbadane ${ }^{1}$.

Celem Agnieszki Teterycz-Puzio w recenzowanej pracy było „,ukazanie kolei życia Konrada Mazowieckiego możliwie wszechstronnie, aby finalnie spróbować ocenić działalność księcia, nie tylko z perspektywy jego współpracy z krzyżakami i bezkompromisowej walki o zdobycie władzy w Krakowie, ale także poprzez pryzmat zarządu swoimi ziemiami” (s. 11). Badaczka postawiła również przed sobą zadanie weryfikacji czarnej legendy władcy, co jej się chyba w dużej mierze udało. Swoje miejsce znalazło w książce też "ludzkie” oblicze Konrada, przez ok. 40 lat męża jednej kobiety i ojca — nawet jak na warunki średniowiecza - sporej grupki dzieci.

Biografia ma chronologiczno-rzeczowy układ, dzięki czemu konstrukcja pracy wydaje się dosyć jasna i przejrzysta. Autorka podzieliła książkę na 5 rozdziałów. Całość zwieńczają: Wykaz skrótów, Bibliografia oraz Indeks osób.

W rozdziale I opisano sprawy genealogii księcia oraz omówiono okres jego życia do objęcia samodzielnych rządów na Kujawach i Mazowszu.

W kolejnym rozdziale, zawierającym opis wydarzeń z lat 1205-1227, A. Teterycz-Puzio przedstawia kolejno relacje Mazowieckiego i jego brata Leszka Białego z władcami Rusi halicko-włodzimierskiej, kwestię polityki względem Prus wraz z brzemiennym w skutki słynnym sprowadzeniem Krzy-

\footnotetext{
${ }^{1}$ H. Samsonowicz: Konrad Mazowiecki (1187/88-31 VIII 1247). Kraków 2008.
} 
żaków do Polski. Na końcu historyk analizuje wydarzenia na wiecu w Gąsawie, podczas którego zginął Leszek Biały. Słusznie - moim zdaniem - autorka broni mazowieckiego władcy przed zarzutem uczestnictwa w spisku na życie brata, gdyż w ówczesnych warunkach politycznych Konrad na nagłej śmierci krakowskiego princepsa zyskiwał najmniej ze wszystkich Piastów obecnych na kolokwium.

Rozdział III: Działalność Konrada I Mazowieckiego w latach 1227-1243 - Kraków czy ziemia chetmińska?, jest najdłuższy. Oddaje ewoluujący stosunek panującego do działań zakonu krzyżackiego. Uwaga badaczki skupia się tu jednak głównie na sprawie najważniejszej dla Mazowieckiego w tym okresie, czyli na próbach zdobycia władzy w Krakowie, a następnie na jej sprawowaniu. Należy się chyba zgodzić z kończącym rozdział stwierdzeniem A. Teterycz-Puzio, że głównym powodem klęski panowania Konrada w Krakowie stało się niedocenienie przez niego politycznej siły możnych małopolskich, z których zdaniem kompletnie się nie liczył. Uważam, że brak zrozumienia dla konieczności współpracy z możnymi zapewne wynikał z ich o wiele słabszej pozycji na Mazowszu niż w księstwie krakowsko-sandomierskim.

Rozdział IV przedstawia wydarzenia lat 1243-1247, kiedy mimo przegranej bitwy pod Suchodołem książę — przy wsparciu różnych, zewnętrznych sojuszników — próbował odebrać władzę w Krakowie swojemu bratankowi Bolesławowi V Wstydliwemu.

Rozdział V: „Kniaź wielki lacki” — bilans rządów, jak wskazuje jego tytuł, jest próbą oceny postaci i wszelkiej działalności politycznej głównego bohatera monografii.

Autorka w swojej książce oparła się na dość rozległym materiale źródłowym i dobrała wcale niemałą literaturę przedmiotu. Brakuje jednak tak podstawowej pracy, jak wysoko ceniona rozprawa Marii Syski o dokumentach władcy ${ }^{2}$. Odnotować trzeba także nieobecność niektórych artykułów Joanny Jacniackiej, Jadwigi Karwasińskiej czy Adriana Jusupovicia³

Recenzując niniejszą biografię księcia Konrada Mazowieckiego, należy przedstawić pewne, czasem bardzo surowe, spostrzeżenia i uwagi. Jak na postać tego formatu zaprezentowany we Wstępie stan badań wydaje się dosyć skromny (s. 13-14). Pisząc o bitwie pod Zawichostem, historyk słusznie zauważa, że polskie źródła nie są obiektywne wobec postępowania księcia

${ }^{2}$ M. Syska: Dokumenty Konrada Mazowieckiego. Warszawa 1967 (praca magisterska, maszynopis, Archiwum Uniwersytetu Warszawskiego, nr alb. 31 813).

3 J. Jacniacka: Walka Ks. Konrada Mazowieckiego z Henrykiem Brodatym pod Skała i Międzyborzem oraz ich nastęstwa. W: Prace historyczne wydane ku uczczeniu 50-lecia Akademickiego Koła Historyków Uniwersytetu Jana Kazimierza we Lwowie 1878-1928. Lwów 1929; J. Karwasińska: Sasiedztwo kujawsko-krzyżackie 1235-1343. W: Taż: Kujawy i Mazowsze. Wybór pism. Warszawa 1997; A. Jusupović: „Domus quondam Dobrinensis”. Przyczynek do dziejów templariuszy na ziemiach Konrada Mazowieckiego. Zap. Hist. 2006, T. 71, z. 1. 
Romana Mścisławowicza, ponieważ ich zadaniem było „sławienie czynów polskich władców" (s. 41). Jednostronne przekazy Rocznika kapitulnego krakowskiego i Kroniki wielkopolskiej autorka przeciwstawia Kronice halicko-wołyńskiej, opiewającej dokonania i pozytywne cechy charakteru Romana (s. 40-41), w ogóle nie zauważając, że źródło to powstało przecież na dworach synów i wnuków Mścisławowicza ${ }^{4}$. Zaraz potem badaczka wspomina o kolejnym przekazie o księciu Romanie, mianowicie o kronice Alberyka z Trois-Fointaines, dodając, że dzieło to powstało ok. 1260 roku (s. 41), podczas gdy Andrzej M. Wyrwa określił powstanie tego tekstu na drugą ćwierć XIII wieku ${ }^{5}$ W książce ponadto wyraźnie brakuje wyjaśnienia wszystkich — podnoszonych przez historyków - wątpliwości genealogicznych dotyczących dzieci Konrada i Agafii. Wyliczając ich potomstwo (s. 49), A. Teterycz-Puzio pomija istnienie w polskiej historiografii teorii o dwóch „Siemowitach”, przy informacjach o córkach natomiast warto może byłoby wspomnieć, że Dubrawka kojarzona była z Heleną, domniemaną córką Leszka Białego. Należy również zasygnalizować, że kanclerz Mikołaj, funkcjonujący w historiografii jako Repczol, nie wiedzieć czemu nazywany jest przez historyk Repczołem, a jakby tego było mało, w tytule zamieszczonego w Polskim stowniku biograficznym biogramu Mikołaja pióra Józefa Mitkowskiego autorka także zmieniła Repczol na Repczoł (s. 137, 159).

Datowane przez badaczkę na rok 1235 inkastelacje według najnowszych ustaleń mają dotyczyć lat 1231 -1232 (s. 141)7. Opisując karierę wielkiego możnego Mściwoja, A. Teterycz-Puzio nie wzięła pod uwagę ostatnich ustaleń na temat kolejno sprawowanych przez niego urzędów po ponownej zmianie daty wiecu w Korytnicy (s. 158-159) ${ }^{8}$. Historyk nie zdziwiło, że w czasie kiedy — jak sama o tym wspomina - Bolesław Wstydliwy w 1242 roku po ucieczce przed Mongołami przebywał poza granicami swojego księstwa, wystawił dokument, w którym pojawił się jako dux Sandomirie. Autorka odwołała się do dyplomu wydanego w Kodeksie dyplomatycznym Polski z datą 5 maja 1242 roku (s. 182)9. W rzeczywistości jest to dokument wystawiony dokładnie 10 lat wcześniej przez księcia sandomierskiego Bolesława Konradowica (a więc brata stryjecznego Wstydliwego), a z prawidłową datą został on wydany przez

${ }^{4}$ Zob. A. Jusupović: Kronika halicko-wotyńska (Kronika Romanowiczów) w latopisarskiej kolekcji historycznej. Kraków-Warszawa 2019, passim.

5 A.M. Wyrwa: Alberyk z Trois-Fontaines i jego średniowieczna Kronika świata. W: Cognitioni gestarum. Studia z dziejów średniowiecza ofiarowane prof. Jerzemu Strzelczykowi. Red. A.A. Sikorski, A.M. Wyrwa. Poznań 2006, s. 331-338.

6 O. Balzer: Genealogia Piastów. Kraków 1895, s. 290-291, 309-313.

7 D. Niemiec: Trzynastowieczne fortyfikacje Krakowa. „Studia nad Dawną Polską” 2017, T. 5, s. 89-90.

${ }^{8}$ Zob. W. Zawitkowska: O wiecu w Korytnicy raz jeszcze. „Limes. Studia i materiały z dziejów Europy Środkowo-Wschodniej" 2008, nr 1, s. 17-18.

9 KDP, T. 2, cz. 1, nr 31. 
Franciszka Piekosińskiego ${ }^{10}$. Badaczka słusznie podniosła duże znaczenie zjazdu mającego odbyć się 18 września 1241 roku. Jako miejsce spotkania Konrada Mazowieckiego z pomorskim księciem Świętopełkiem podała Pomuzow (s. 183-184). Obecnie w nowszej literaturze określa się kolokwium jako odbyte na Kępie bądź Wyspie Pędzewskiej niedaleko Solca Kujawskiego ${ }^{11}$. O innym zjeździe A. Teterycz-Puzio pisze jako odbytym nad rzeczką "Mirawą" (np. s. 201). Chodzi tu o rzekę Mierzawę, prawobrzeżny dopływ Nidy.

Ze zdziwieniem przeczytałam, że Bronisław Włodarski — zdaniem historyk - przedatował pewną wyprawę z podanego przez Kronikę halicko-wotyńska roku 1245 na lata 1243 i 1244 (s. 204, przyp. 92). Jedną z najbardziej charakterystycznych cech wspomnianego źródła ruskiego jest brak rocznej siatki podziału tekstu ${ }^{12}$, a „Dokładna datacja poszczególnych fragmentów wymaga zestawienia ich z innymi źródłami europejskimi, zarówno napisanymi po łacinie, jak i cyrylicą"13. Na początku rozdziału $\mathrm{V}$ autorka - porównując najbardziej skrajne obrazy tytułowego bohatera obecne w źródłach — odwołuje się do Kroniki halicko-wotyńskiej, nazywającej władcę m.in.: „kniaziem wielkim lackim”, „sławnym” czy „przedobrym” (s. 211). Zestawiając celowo tego typu źródła w tym miejscu, badaczka powinna wiedzieć i poinformować czytelników, że określenie to jest częścią noty obituarnej, a w takich okolicznościach zwykle w ten sposób przedstawiano „lackich kniaziów”"14. Jest to tym bardziej istotne, że określenie „kniaź wielki lacki” występuje przecież w tytule książki.

A. Teterycz-Puzio popełniła dosyć dużo błędów redakcyjnych i warsztatowych. Nie tylko niezliczone (stąd niemożliwe do wynotowania w niniejszym artykule) literówki i błędy interpunkcyjne w tekście pracy dają efekt niechlujstwa historyk. Czasem odnosi się wrażenie, że w książce są błędy, których poważny naukowiec może dopuścić się tylko z sobie wiadomych przyczyn, z premedytacją. Jeśliby zawierzyć autorce, biogram księżnej Heleny, żony Kazimierza Sprawiedliwego, w Polskim stowniku biograficznym posiada niebagatelną liczbę 101 stron (s. 18, 241). Przywołując argumenty za objęciem przez Konrada władzy na Mazowszu ok. 1200 roku, badaczka odwołuje się do zdania Błażeja Śliwińskiego, w odpowiednim przypisie nie ma jednak wzmianki o jakiejkolwiek pracy gdańskiego historyka, jedynie dokument, na którym B. Śliwiński oparł swoją teorię (s. 31). A. Teterycz-Puzio podaje za Mariuszem Bartnickim

${ }^{10}$ KDM, T. 2, nr 403.

11 B. Śliwiński: Pogranicze kujawsko-pomorskie w XII-XIII wieku. Z dziejów Bydgoskiego $i$ Wyszogrodzkiego w latach 1113-1296. Warszawa-Poznań 1989, s. 145; M. Smoliński: Świętopetk Gdański. Poznań 2016, s. 220-221.

${ }^{12}$ Kronika halicko-wotyńska. (Kronika Romanowiczów). Wydali, wstępem i przypisami opatrzyli D. Dąbrowski, A. Jusupović, przy współpracy I. Juriewej, A. Majorowa i T. Wiłkuł. W: MPHn. T. 16. Kraków-Warszawa 2017, s. 44.

13 A. Jusupović: Kronika halicko-wotyńska..., s. 16.

${ }^{14}$ Zob. Kronika halicko-wotyńska. (Kronika Romanowiczów)..., s. 180; por. informacje o śmierci Leszka Białego i Bolesława V Wstydliwego — tamże, s. 135, 232. 
(nazwanym przez nią Markiem Bartnickim) informację o spotkaniu Pakosława Starego z Danielem Romanowiczem, a w stosownym przypisie umieszcza pracę Dariusza Dąbrowskiego. Mnóstwo razy mocno rzucają się w oczy błędy warsztatowe w przypisach (np. s. 86, 98, 110, 119, 130, 151, 155, 157, 167, 176, 186, 189). W przypadku odwołań do Preussisches Urkundenbuch raz pojawia się odpowiedni tom zbioru dokumentów, a innym razem nie (por. np. s. 63, przyp. 157, s. 66, przyp. 175). Należy też zaznaczyć, że znany mediewista Labuda, który otrzymał nowe imię - Gerald (s. 86, 92, 94, 111-112, 179), nie został uwzględniony w Indeksie osób (s. 262), natomiast Witold Garbaczewski nosi nazwisko Gorbaczewski (s. 128, 243). A. Jusupović z kolei we wszystkich możliwych miejscach jest nazywany Jusupowiciem (s. 13, 213, 238, 244). Kolejną kwestią jest to, że, nie wiedzieć czemu, historyk korzystała ze starego wydania Kroniki halicko-wotyńskiej, pochodzącego z 1908 roku (s. 102, przyp. 405) trzeba, że autorka znała i jednocześnie wykorzystywała w recenzowanej pozycji polską wersję najnowszej edycji kroniki, która powstała jednocześnie z wersją cyryliczną ${ }^{16}$. Warto również nadmienić, że badaczka z takim doświadczeniem powinna być już oswojona $\mathrm{z}$ łacińską tytulaturą najważniejszych urzędników epoki średniowiecza. Cześnik mazowiecki określony zostaje jednak przez nią jako pancerna Mazouie, a autorka informuje (niezgodnie z prawdą) w odpowiednim przypisie, że taki zapis znajdował się w książce Kazimierza Pacuskiego ${ }^{17}$ (s. 164). Istotnym błędem jest to, że w bibliografii nie ma wymienionych wszystkich prac wykorzystanych w biografii. Brak choćby artykułu Tomasza Jurka o zamachu w Gąsawie, Iwony Okraszewskiej o księżnej Agafii, biogramu Mikołaja Repczola autorstwa J. Mitkowskiego czy monografii K. Pacuskiego o możnowładztwie i rycerstwie ziemi gostynińskiej. Ponadto, sporządzając bibliografię, A. Teterycz-Puzio pomyliła kolejność nawet swoich własnych artykułów (s. 254).

Szczytem nierzetelności warsztatowej zaprezentowanej przez historyk jest sposób zacytowania fragmentów Kroniki halicko-wołyńskiej na s. 129-130 biografii, gdzie doliczyłam się co najmniej kilkunastu poważnych błędów. Autorka zmienia przytaczany tekst, nawet jeśli „,nowa” wersja ma być niepoprawna stylistycznie (,zajęli i złupili łupy wielkie” zamiast „zajęli i zdobyli łupy wielkie"), pomija słowa w cytowanych fragmentach, nie oznaczając takowej zmiany, źle określa przytaczane strony Kroniki... (przyp. 128), w końcu powołuje się na fragment cyrylicznej wersji dzieła, z którego w danym miejscu jednak nie korzysta (przyp. 129) ${ }^{18}$.

${ }^{15}$ Ипатьевская летопись. В: Полное собрание русских летописей. Изд. А. Шахматоь. Санкт-Петербург 1908 [переиздание: Москва 1962].

${ }^{16}$ Zob. Kronika halicko-wolyńska. (Kronika Romanowiczów)...

${ }^{17}$ K. Pacuski: Możnowtadztwo i rycerstwo ziemi gostynińskiej w XIV i XV wieku: studium z dziejów osadnictwa i elity władzy na Mazowszu średniowiecznym. Warszawa 2009, s. $410-411$.

${ }^{18}$ Całość uwag por. Kronika halicko-wołyńska. (Kronika Romanowiczów)..., s. 136. 
Recenzowana praca $\mathrm{z}$ pewnością $\mathrm{w}$ wielu miejscach systematyzuje dotychczasowy stan badań. Często jednak - nawet w bardzo ważnych kwestiach brakuje wyraźnego własnego zdania autorki. Wiele razy A. Teterycz-Puzio opiera się tylko na hipotezach innych badaczy. Niemniej jednak Konrad Mazowiecki jest postacią tak kontrowersyjną, intrygującą i ciekawą, że duże błędy i nieścisłości $\mathrm{w}$ jego biografii nie są $\mathrm{w}$ stanie jej zdegradować do poziomu książki, po którą nie warto sięgnąć.

Karolina Maciaszek

iD https://orcid.org/0000-0001-8606-810X 